\title{
So You Want To Go Digital? How To Avoid The Next Legacy Platform Debacle
}

\author{
Martin Mocker \\ Reutlingen University and MIT \\ martin.mocker@reutlingen-university.de
}

\author{
John Boochever \\ Oliver Wyman \\ john.boochever@oliverwyman.com
}

\begin{abstract}
IT platforms as the foundation of digitized processes and products are vital in a digital economy. However, many companies' platforms are liabilities, not strategic assets because of their complexity. Consequently, companies initiate IT complexity reduction programs. But these technology-centric programs at best provide temporary relief. Soon after, companies' platforms become just as complex as before. Based on four case studies, we identify three non-technical drivers of platform complexity: (1) Lacking awareness of consequences business decisions have on platform complexity, (2) Lacking motivation to avoid platform complexity, (3) Lacking authority to protect platforms from complexity. We propose measures to address these drivers that can help achieve more sustainable impact on platform complexity: (1) Removing information asymmetries between those creating complexity and those dealing with complexity, (2) Redefining incentives to include long-term effects on platform complexity, (3) Redressing power imbalances between those who create complexity and those who have to manage it.
\end{abstract}

\section{Introduction}

No company can successfully compete in the digital age without a working digital platform - the infrastructural technologies, software applications and data that allow companies to sell products online, to automate internal processes, to analyze vast amounts of information to make better decisions and, increasingly, to build smart, connected products [23, 17]. These platforms are viewed as the "digital foundation" of companies and have been defined as "the IT infrastructure and digitized business processes automating a company's core capabilities.” [19].

However, for many large companies, their current platforms are more of a liability than a strategic asset. Over time, "legacy" systems have grown so complex that they stifle companies by making it difficult for employees to get things done, by making it cumbersome for customers to deal with the company, and by forcing managers into 'flying without instruments' when it comes to steering parts of their companies [15, 3 p. 13]. The inability to view a customer's transaction history across different business units or having to manually reconcile information about customers from different databases are common examples of negative impacts of platform complexity. As platform complexity eventually results in lost revenue or higher costs, companies fight it [3].

Referring to "IT or enterprise architecture complexity," researchers have proposed several metrics for platform complexity including the size, diversity, integration and rate of change of IT artifacts on various architectural levels like IT infrastructure, applications, and information [1, 20, 8, 21].

In reaction to growing complexity, many companies initiate IT complexity reduction programs [3] addressing one or multiple of these platform complexity metrics. For example, Akzo Nobel is moving from over 180 different ERP systems to only six [7]. Some even attempt to replace existing platforms with new, "green field” platforms: Philips is replacing its 10,000 systems with a few hundred that form their Philips Integrated Landscape [14].

Even if they succeed, many of these IT complexity reduction initiatives often only provide temporary relief. A few years later, after the introduction of new products, geographic growth, the addition of new channels, most companies find themselves dealing with a platform that is just as complex as it was before the simplification initiative. But as we are experiencing a more and more digital economy, complex digital platforms are becoming even more of a liability as companies increasingly start to expose their platforms via APIs to external parties [22] and platforms start featuring as core enablers of smart, connected products directly used by customers [23, 17, 16].

But how can executives avoid building the next complex legacy platform when taking their companies into the digital age? Based on in-depth case studies, research interviews with executives from other 
companies, and the experience - even if not systematically analyzed - of more than 100 consulting projects in the area of IT complexity over the last five years, this paper identifies three drivers that lead companies to accumulate complexity in their digital platforms. The paper also proposes how companies can address these three drivers in order to avoid building the next legacy platform of the future.

\section{About the research}

To answer our research question ("how can companies avoid building the next complex legacy platform?”) we followed a case-based approach. We interviewed 35 IT and business executives on their challenges on complexity and how they addressed them in an exploratory fashion. These interviews confirmed the relevance of the issue and provided a basis for selecting case studies. We conducted several in-depth case studies for selected companies, out of which we refer to four in detail in this article. In these companies, we interviewed a total of 43 (ING Direct Spain: 3, DHL Express: 7, USAA: 17, Royal Philips: 16) employees from IT and non-IT parts ranging from C-level to project management level. We selected the companies as they addressed IT platform complexity challenges in convincing ways and stood out compared to the other companies we had interviewed. They either went through situations of growth or change on the business side (ING Direct Spain, USAA) that often lead to excessively complex IT platforms, but didn't in these cases; or they had highly complex platforms and employed measures to avoid this from happening in the future (Philips, DHL Express).

One author and another researcher wrote up individual case studies [11, 10, 13, 14] based on transcribed interview data. The two authors of this article then analyzed them for commonalities across cases (see Table 1). The coding categories were based on concepts we derived from game-theoretic works [2, 4, 5, 6]: information asymmetries, incentives, and power differentials. Game theory has most often been used to explain strategic moves on an inter-company level where there is incomplete or asymmetrical information. But it can be applied equally to decisions within the corporate environment, like the decisions of whether and how to deploy new technology [4]. A key insight derived from game theory addresses how decentralized teams (like IT and non-IT groups) deal with proprietary information and bargain with each other to reach agreements [2, p. 804]. When those teams don't have equal access to the available information, the solutions (or the platform in our case) they arrive at will be inefficient. If each bargainer knows something relevant that the other does not, such as the payoff from a successful agreement, bargains that should ideally be struck are likely to be delayed or rejected [5, p. 115].

Power differentials serve to rig the bargaining system in favor of the more powerful or knowledgeable party - in this case perhaps business units (BU) over central IT. And this power differential has significant implications: while one party (i.e., central IT) has the fuller picture, it may lack the power to insinuate that view into the more powerful party's (i.e., the BU's) decision-making [4, p. 50]. Applying game theory helps us redefine the problem of platform complexity as an organizational, behavioral and management issue, rather than a technical problem.

After the cross-case analysis, we went back to previous single company interviews [9] and existing case studies on other companies $[12,18]$ that were not primarily on complexity but covered the topic at least in some depth. We did this to identify examples that further illustrated or countered our findings, and also to extend the range of industries covered. These are included in the last column in Table 1.

\section{Description of the case companies}

Below we introduce the companies and explain why we selected them for this research.

\subsection{Royal Philips}

Royal Philips was founded in 1891 in Eindhoven, The Netherlands. In 2013, Royal Philips operated in 15 Business Groups comprising over 60 Business Categories. Each Business Group belonged to one of three Sectors: Lighting (e.g., city street lighting, automotive lighting, consumer luminaires, etc.), Healthcare (imaging systems, integrated healthcare solutions, healthcare software, etc.) and Consumer Lifestyle (e.g. personal care, household products, computer accessories, etc.). With these products, Philips served customers in over 100 countries clustered into 17 markets (North America, China, etc.).

Throughout its history, Philips' products have been widely respected. In 2013, Philips was the most valuable brand in The Netherlands, with Interbrand ranking it 40th among the 100 most valuable brands globally. Despite its brand and innovations, Philips' financial performance was flagging early in the new millennium. From 2000-2010, Philips lost more than $40 \%$ of its revenue and its profit margin had dropped from $25 \%$ to $7 \%$ after losses in several years.

On April 1, 2011, Frans van Houten was named CEO and tasked with turning around the business with the Accelerate! transformation. Financially, the 
transformation promised EBITA margins of 11-12\% by the end of 2016 and $10-12 \%$ by the end of 2013 while growing sales at a CAGR of 4-6\% between 2014 and 2016. All mid-term goals for 2013 were reached and shareholder's confidence as its share price had doubled since its most recent low point in late 2011.

One of the key challenges the transformation was facing was the large degree of freedom previously granted to P\&L responsible product managers. This led to a proliferation of non-standardized business processes supported by more than 10,000 applications. For example, Philips was running a total of around 60 different ERP systems. No wonder Philips found that within one sector, it had 17 different ways of sending invoices to customers [14] which proved both costly for Philips and cumbersome for customers. In response, Philips' new CIO designed a new "green field" IT landscape for all of Philips: the so called Philips Integrated Landscape (PIL) that supported three newly defined globally standardized processes: idea-tomarket (concerned with turning an idea into a product, service, software or system, bringing it to the market and managing the product lifecycle), market-to-order (concerned with marketing the product and generating sales orders), and order-to-cash (concerned with the processing of an order including, for example, fulfillment, distribution, invoicing, payments handling). Philips is an example of a company that then also had to employ measures to avoid creating the next legacy platform despite the targeted growth [14].

\subsection{USAA}

Founded in 1922, Texas-based financial service provider USAA has grown its product portfolio from auto insurance to over $100 \mathrm{P} \& \mathrm{C}$ and life insurance, banking, and investment management products.

More recently, USAA has also created connections between different products by linking them in integrated services addressing life events. Life events like buying a car or house-or getting marriedinvolve multiple products such as loans and insurance. Introduced in 2010, one of the company's first integrated services targeted the car buying life event, allowing members to select, buy (at a pre-negotiated price), finance, and insure a car in one seamless process. While this made its members' (this is how USAA calls its customers), lives easier, the need to integrate can easily create a "spaghetti"-type platform.

Instead, USAA leveraged a single "customer information file" to provide a 360 degree view of the customer across products. USAA had managed to maintain a manageable platform since its development in 1984. Also, USAA invested less than half its IT budget in running systems. In 2012, average project delivery time was 125 days, which was significantly below industry average and a reduction of more than 50 days from 2009. Ninety-three percent of projects were delivered on time, and in 2012 USAA was concurrently working on nearly 250 projects. By 2012, $50 \%$ of the functionality in new systems was reused from existing components. In 2011, USAA's 23,400 employees generated revenues of $\$ 19$ billion, an increase of $6.7 \%$ over 2010 . Its net profit margin of $11.2 \%$ compared to an industry average of $2.2 \%$. Its 8.8 million members in 2011 constituted a 10\% increase over 2010 with a $98 \%$ retention rate. USAA had long focused on providing an excellent customer experience. Its success in this regard was reflected in its Net Promoter Scores (NPS): in the 2011 Satmetrix Net Promoter Benchmark Study of US Consumers, USAA led in the Auto Insurance, Banking and Homeowners Insurance industries with scores that were at least double the industry average scores [10].

\subsection{ING Direct Spain}

ING Direct was founded as part of ING Group in 1997. After Canada, ING Direct Spain had been the second country world-wide of ING Direct.

ING Direct Spain is an example of a company that showed strong growth, while keeping its IT platform's complexity at bay. Originally started as a mono-line business focused purely on savings accounts, over time ING Direct Spain had become a full-service bank. To achieve that goal, the direct bank had substantially increased its portfolio of products (including loans, credit cards, mortgages, life insurance, brokerage services, etc.) and channels (including the phone, the web, mobile apps, and even 30 branches).

The increased variety in the product portfolio was viewed as creating value for ING Direct Spain: In 2011, ING Direct Spain reported 77 million EUR in profits before tax (a 9-year CAGR of 28\%) and 2.41 million customers (a 9-year CAGR of $16 \%$ ), of which more than 700,000 used ING Direct Spain as their main bank. Citing the Association of Spanish Banks, ING Direct Spain took pride in being the "leading direct bank in Spain,” with managed funds that totaled 29.9 million EUR and 940 employees.

At the same time, operating fixed-cost per customers had grown by only $20 \%$ since 2005 . An IT cost benchmark performed by an independent consulting firm revealed ING Direct to be best-in-class in the Spanish market. Its cost per account had dropped by 25\% between 2008 and 2011. Also in terms of total operations cost per account, ING Direct Spain continued to be very efficient. One benchmark compared ING Direct Spain's costs per account to ten Eastern \& Central European banks that were deemed 
comparable in terms of scale. ING Direct Spain's costs per account were somewhat below the average of the top three banks in the sample which was less than half of the cost of the average performers in the sample and a third of the average Iberian bank [11].

\subsection{DHL Express}

In 2012, DHL Express ("the most international company on earth") was one of four divisions of Deutsche Post DHL (DPDHL). DHL Express' 100,000 employees transported 1.6 million packages each day for the company's 2.6 million customers. Although all four divisions were profitable and all had revenues ranging between $€ 13$ and $€ 16$ billion, the Express division contributed more than $40 \%$ of the group's profit. DHL Express had become profitable in 2010 and enjoyed 8.7\% Return on Sales in 2012.

But that hadn't always been the case. From 2004 2008, the losses in the US alone grew at an annual rate of $24 \%$, eventually topping $\$ 1$ billion. As one of the levers to turn around the business, the company had introduced a set of global business and technology standards known as Express Global Application Portfolio or EGAP. Moving the US business to the global standard meant replacing the current international shipping processes and supporting 600 systems with around EGAP processes supported by around 145 systems. Examples of the issues created by non-standardized processes and systems were that employees could not be deployed globally and information of global customers was dispersed.

But even if all regions conformed to a common standard, the challenge was an ongoing one: how to maintain a truly global standard. Especially with DHL operating in 220 countries and territories, changing regulations and pressures for modifying the global standard in order to serve local customers better came up regularly. And with 100,000 employees, ideas for improving standard practices popped-up everywhere.

We selected the DHL Express case for this research as the company developed mechanisms to deal with requests for changes to the global standard, i.e. aiming at avoiding a future increase in complexity [13].

\section{Findings: 3 drivers of platform complexity and how to counter them}

Our case companies employed technical and nontechnical practices to address platform complexity for the long term. The technical practices aimed for "smart design” of their IT platforms (e.g., designing for reuse, for decoupling, for configuration instead of customization). The idea underlying these practices is that following certain design principles will lead to IT platforms that will be less complex and that will be able to "absorb" complexity caused by increasing and changing business requirements.

We built [an auto insurance system] entirely for the web, but because we used good design [...] and good business rules isolation, it was very easy to send it to the phone. It was also very easy to put a new line of business on that system because the rating was separate from underwriting, which was separate from the presentation. - James S. Kuhn, SVP, Project Delivery, USAA

But designing systems technically for lower complexity isn't enough. In the long term, other factors seem to matter at least as much as - if not more than engineering design principles.

[The biggest risk] is that business reverts back into the "I want this, you [IT] go and do it" mode, the old pecking order. [...] It's not that people don't buy in on the logic, I think they do. They revert back to their old behaviors, because they are deeply ingrained. So the biggest obstacle is mindset. —Jeroen Tas, EVP and CIO, Philips

We identified three non-technical drivers that cause companies to incur complexity in their IT platforms none of which have to do with the technology itself, but rather with those who create and manage the complexity and their decision making, i.e, people and their behavior (see Table 1).

\subsection{Lack of awareness of the consequences business decisions have on platform complexity}

Customer service employees dealing with customers who have to log in multiple times to access different products, operational-level employees having to enter the same data multiple times, IT people having to maintain hundreds of intertwined IT systems - they all experience the impact of platform complexity every day. And they can predict the consequences of introducing yet another product modification, or of opening the new mobile channel on IT complexity pretty well. Product managers, who are adding "only one more product" cannot. This mismatch between those creating complexity (with the best intentions) and those having to deal with it is a source of complexity.

When [the product departments] design a product, they might make complex things, then people for example in customer service will suffer and the customer will suffer. Or we put together something that is operationally so complex that it will produce complaints in the future. -Daniel Llano

EVP Products \& Strategy, ING Direct Spain 
Table 1: Mapping the drivers of platform complexity and their counter-measures to our cases

\begin{tabular}{|c|c|c|c|c|c|}
\hline $\begin{array}{l}\text { Drivers of digital } \\
\text { platform complexity I } \\
\rightarrow \text { measures to } \\
\text { address each driver }\end{array}$ & Royal Philips [14] & USAA [10] & $\begin{array}{l}\text { ING Direct } \\
\text { Spain [11] }\end{array}$ & $\begin{array}{l}\text { DHL Express } \\
\text { [13] }\end{array}$ & Other examples \\
\hline $\begin{array}{l}\text { Lack of awareness of } \\
\text { the consequences } \\
\text { business decisions } \\
\text { have on platform } \\
\text { complexity } \\
\rightarrow \text { Creating } \\
\text { transparency by } \\
\text { removing information } \\
\text { asymmetries between } \\
\text { those creating } \\
\text { complexity and those } \\
\text { having to deal with } \\
\text { complexity }\end{array}$ & $\begin{array}{l}\text { Cross-functional } \\
\text { trainings. } \\
\text { Multi-disciplinary } \\
\text { teams including IT. } \\
\\
\text { Provide anecdotal } \\
\text { evidence of } \\
\text { complexity cost } \\
\text { [see quote P1 } \\
\text { below, not included } \\
\text { in table due to } \\
\text { space limitation] }\end{array}$ & $\begin{array}{l}\text { IT architects } \\
\text { engaged in every } \\
\text { significant project, } \\
\text { helping } \\
\text { communicate } \\
\text { impact on IT } \\
\text { platform. } \\
\text { Regular job } \\
\text { transfers between } \\
\text { departments. } \\
\text { IT reporting } \\
\text { regularly on } \\
\text { metrics like re-use }\end{array}$ & $\begin{array}{l}\text { IT employees } \\
\text { involved early } \\
\text { on in cross- } \\
\text { functional } \\
\text { teams in } \\
\text { product dev. } \\
{[11,12,13]} \\
\text { Onboarding } \\
\text { new hires } \\
\text { always } \\
\text { involved a } \\
\text { short "tour of } \\
\text { duty" in every } \\
\text { dptmnt. [14] }\end{array}$ & $\begin{array}{l}\text { Regular "audits" } \\
\text { by cross- } \\
\text { functional team } \\
\text { including site } \\
\text { visits that } \\
\text { communicate } \\
\text { standard } \\
\text { compliance to } \\
\text { each unit. [D1] }\end{array}$ & $\begin{array}{l}\text { IBM: regular job } \\
\text { transfers } \\
\text { between } \\
\text { departments [9] } \\
\text { Pharma } \\
\text { company: ClO } \\
\text { uses mobile app } \\
\text { to show business } \\
\text { the number of } \\
\text { apps already } \\
\text { maintained for } \\
\text { the unit }\end{array}$ \\
\hline $\begin{array}{l}\text { Lack of motivation to } \\
\text { avoid complexity in } \\
\text { digital platforms } \\
\rightarrow \text { Redefining } \\
\text { incentive systems to } \\
\text { include long-term } \\
\text { impacts on the } \\
\text { complexity of digital } \\
\text { platforms }\end{array}$ & $\begin{array}{l}\text { Move beyond } \\
\text { individual business } \\
\text { cases to enterprise- } \\
\text { wide thinking (and } \\
\text { establish in decision } \\
\text { making criteria for } \\
\text { starting projects) } \\
\text { [P2, P3] }\end{array}$ & $\begin{array}{l}\text { Overarching } \\
\text { mission ("financial } \\
\text { security of } \\
\text { members") used to } \\
\text { resolve } \\
\text { operational trade- } \\
\text { offs [U1, U2] } \\
\text { Company reward } \\
\text { system paying out } \\
\text { same percentage } \\
\text { bonus (after } \\
\text { reaching personal } \\
\text { goals) } \\
\text { IT has } \\
\text { demonstrated } \\
\text { savings in cost } \\
\text { and time of } \\
\text { platform use that } \\
\text { business actively } \\
\text { protects platform. } \\
\text { [U3] }\end{array}$ & $\begin{array}{l}\text { Set rule: only } \\
\text { introduce } \\
\text { products that } \\
\text { have 'scale' } \\
\text { (potential to } \\
\text { reach } 5 \% \text { of } \\
\text { revenues) } \\
\text { Encourage } \\
\text { enterprise- } \\
\text { wide thinking } \\
\text { over silo- } \\
\text { thinking (e.g., } \\
\text { executives } \\
\text { modeling that } \\
\text { behavior) also } \\
\text { reflected in } \\
\text { remuneration } \\
\text { system [15-7] } \\
\text { Overriding } \\
\text { goal beyond } \\
\text { financials: } \\
\text { superior } \\
\text { customer } \\
\text { experience. }\end{array}$ & $\begin{array}{l}\text { Defined process } \\
\text { for requesting } \\
\text { changes to } \\
\text { standard: all IT } \\
\text { investments } \\
\text { above 5,000 } \\
\text { Euro have to } \\
\text { pass through } \\
\text { multi-step } \\
\text { process, ending } \\
\text { at the central } \\
\text { investment } \\
\text { committee } \\
\text { (chaired by the } \\
\text { CEO) [D2, D3] } \\
\text { Exceptions to } \\
\text { standards only } \\
\text { granted for one } \\
\text { year. }\end{array}$ & $\begin{array}{l}\text { Fidelity: Concept } \\
\text { of technology } \\
\text { debt [18] }\end{array}$ \\
\hline $\begin{array}{l}\text { Lack of authority to } \\
\text { protect digital } \\
\text { platforms from } \\
\text { complexity } \\
\rightarrow \text { Removing the } \\
\text { power imbalance } \\
\text { between those who } \\
\text { create complexity and } \\
\text { those having to } \\
\text { manage it (like the IT } \\
\text { unit) }\end{array}$ & $\begin{array}{l}\text { Reversing burden } \\
\text { of proof: by default } \\
\text { business needs to } \\
\text { use standard unless } \\
\text { it can prove legal } \\
\text { requirements or } \\
\text { customer willing- } \\
\text { ness to pay [P4] } \\
\text { Executive Business } \\
\text { Process Owners } \\
\text { (BPOs) part of } \\
\text { Executive } \\
\text { Committee } \\
\text { BPOs synchronize } \\
\text { change requests } \\
\text { across businesses } \\
\text { [P5] } \\
\text { Business process } \\
\text { experts "on the } \\
\text { ground" ensure } \\
\text { standards day by } \\
\text { day [P6] }\end{array}$ & $\begin{array}{l}\text { IT perceived as } \\
\text { trusted advisor } \\
\text { and as being } \\
\text { ahead of the } \\
\text { business vision. } \\
\text { [U4, U5] } \\
\text { Organizational unit } \\
\text { dedicated to } \\
\text { "deliver for the } \\
\text { project, but build } \\
\text { for the enterprise" }\end{array}$ & $\begin{array}{l}\text { Organizational } \\
\text { forums support } \\
\text { cross- } \\
\text { department } \\
\text { collaboration } \\
\text { (incl. e.g. } \\
\text { COO, ClO, } \\
\text { product } \\
\text { leaders). [18] } \\
\text { Veto rights by } \\
\text { other } \\
\text { departments } \\
\text { over P\&L } \\
\text { leaders. [19] }\end{array}$ & $\begin{array}{l}\text { Global (Supply } \\
\text { Side) ClO } \\
\text { member of the } \\
\text { investment } \\
\text { committee }\end{array}$ & $\begin{array}{l}\text { Bayer Material } \\
\text { Science: } \\
\text { reversing the } \\
\text { burden of proof. } \\
\text { [12] } \\
\text { IBM: reversing } \\
\text { the burden of } \\
\text { proof. [O1, O2] } \\
{[9]}\end{array}$ \\
\hline
\end{tabular}


Large commercial insurers in the US have built up a repository of $30,000+$ products as a result of not having a feedback loop about the resulting burden on the organization (underwriters, operations, customer service, IT, regulatory services, etc.).

Looking at companies that have worked hard on avoiding excessive platform complexity, one way to counter this is to create transparency by removing information asymmetries between those creating complexity and those having to deal with complexity. The following examples highlight potential actions:

- The CIO in one global pharma company developed a mobile app to show the number of applications per business unit, per business processes and sub-processes. When being asked by his peers from finance, HR, or sales to build a new system, he pulled out his iPad, launched the app and asked "Can't any of your 80 systems do that for you?" Providing this feedback made business executives aware of the complexity their previous demands had created and started a healthy discussion about re-using existing systems and working on simplification together rather than making it an IT issue. Within three years, the company moved from 4100 to 3000 applications.

- $\quad$ ING Direct Spain and USAA successfully employ cross-functional teams for product development that include IT architects and customer service representatives early on. Architects provide input on the platform impacts of business requirements and propose alternatives with less IT complexity.

[IT] is helping [the business] to redefine requirements. And this involvement is from the very beginning of the ideation process. So there's no mismatch between something that they want to do and what the architecture can deliver because we already challenge, at very initial stages, the business about different approaches, the implication that their requirements might have in the future implementation and maintainability and sustainability of the platform.

—Enrique Avila, CIO, ING Direct Spain

And as the head of products at ING Direct Spain puts it: "When we start thinking about any product, one of the first conversations that we have is with IT. How complex is the process? How do you think it will fit into our IT architecture? Nobody comes into my office and says 'OK, this is a product I want to launch,' without understanding what will be the impact on the whole bank. That can't happen."

- IBM and USAA rotate executives in and out of IT, e.g. Pat Toole used to be the CIO and then became the leader of a business unit. Those leaders now know what complexity does to IBM and act accordingly in their new role.

\subsection{Lack of motivation to avoid complexity in digital platforms}

In most companies we studied, the people with revenue or profit and loss responsibility had the power to make things happen, mostly in favor of what is best for their own local unit.

"Every country manager thinks he's very special, so it's not just the US. It's the Japanese and the Swiss and the Dutch also. [...]." -Patrick

Byron, VP Global Billing, DHL Express

And it is difficult to condemn people to act according to what they are being evaluated for. But as the former CIO of Philips, Jeroen Tas, put it: "Each individual business case may make sense from the local perspective, but if you add them up at the global level [...] many of those cases make less sense." And one of his colleagues, Mats Beem, adds "[In the past] the argument often was, 'I spend \$100,000 in making something special in [our Enterprise Resource Planning system]. And I can demonstrate I get 300,000 back in one year. Why not do this?'” Take all these locally optimal actions together that each add just one more non-standard database system, or deviate in just one more way from the global standard, and you necessarily end up with a complex digital platform.

Some companies we studied reacted by redefining incentive systems to include long-term impacts on the complexity of digital platforms:

- At ING Direct Spain and USAA, corporate-wide incentives count at least as much as local unit incentives, encouraging employees to think about enterprise-wide impacts (including on IT) rather than just their local impacts. The same companies also use multiple, potentially conflicting goals to measure success and hold people accountable (like profitability and customer satisfaction - the latter one is often much more directly impacted by dysfunctional and complex IT systems).

- The improved experience from faster project delivery, lower long-term cost of re-usable platform components have instilled a "pull” from the business side instead of having IT "push" all the time: "Because of 10 years of shared experiences and shared successes, now these business people are the first ones to go, "Oh, don't shortcut, because I want it [the IT system] to be around here a long time." —Jim Kuhn, USAA

- Other organizations (Fidelity Investments is one of them [18]) have established a concept called 
"technology debt." The purpose is to instill some level of accountability with the non-IT side of the business when making IT-related decisions. Often times, the impact of IT-related decisions has a long latency, so the IT unit gets left with the burden of accumulating complexity over time. To offset the negative effect of increasing IT complexity, the technology debt can be a jointly agreed amount that the IT unit charges the business and that is paid off using the benefits from the IT-based solution that was put in place by the business. IT will then use this fund to unravel the complexity over time. While technology debt is seemingly reactive as it is charged ex-post, it is actually a preventive mechanism. As the business starts feeling the weight of the debt, over time, they become more conscious in making certain technology trade-offs.

\subsection{Lack of authority to effectively protect digital platforms from complexity}

More often than not, the IT unit is seen as an "order taker" rather than a thought partner. As a consequence, even those standards and policies set up by the IT unit to fight complexity are circumvented with exceptions or ignored altogether. But because the IT unit is one of those units that feel the impact of complexity every day, it can provide valuable input into decision making - if they are allowed to and have "a seat at the decision making table.” Some companies are hence removing the power imbalance between those who create complexity and those having to manage it (like IT):

- The CEO of Bayer Material Science empowered the CIO to reduce the variety of ERP systems around the globe as part of their "Program One" by "reversing the burden of proof": instead of having IT argue with every country manager on whether they could adapt to the global company standard, by default country managers had to adopt the new global standard, unless they could prove that deviating from the standard had more benefits for the company as a whole than not doing so. [12]. At Philips, as well as at IBM, business units need to prove a "customer's willingness to pay" for the benefits that cause added complexity or legal requirements before they are allowed to deviate from the global standard: "But if you say it cannot be standard, you'd better bring a lawyer, because then it has to have a legal or a compliance background." Mats Beem, SVP, E2E IT Landscape Simplification, Philips.

- Philips introduced Executive Business Process Owners (BPOs) who are members of the executive committee and are the only ones who can order IT changes: "We won't do anything unless the BPO community, acknowledges that this is the right thing to do. We're no longer going to ask some guy in some business unit deep down what their needs are. No, we are dealing with [the BPO] to prioritize what's going into [the systems]. She or he is responsible to make sure he gets the input from the [business units]. It used to be the other way around: I'm a business unit and I need to go and do this." -Jeroen Tas, EVP and CIO, Philips At the same time, Philips is assigning several people the role of Business Process Expert who are accepted experts in their job and who watch out for unnecessary complexity additions: "Real learning happens for $90 \%$ 'on the job,' so you need people on the shop floor where the action is to actually raise their hands and ask: 'This is not the way according to the standard, why are you deviating?' To get the right level of discipline." -Rob Theunissen, Transformation Leader).

\section{Guidelines for practitioners}

Probably the most common way of dealing with IT platform complexity we've found is by addressing it on a technical level through the likes of serverconsolidation and application rationalization. But such complexity reduction happens 'after the fact' and often turns into a never-ending task as complexity seeps in with ever-increasing and -changing business demands.

To address platform complexity more sustainably, a technical, "reduce complexity after the fact" approach needs to be complemented with one that influences behavior and seeks to curb complexity before it is created. To do so, executives might want to consider the three levers we identified (see Table 1):

1) Address unawareness of the consequences business decisions have on the complexity of digital platforms. Executives need to create transparency by removing information asymmetries between those creating platform complexity and those having to deal with platform complexity. This is best done by bringing those two groups of people together. Hence, most of the practices in Table 1 support creating a common understanding by bringing together cross-functional teams including IT, product management, customer service etc. The call for creating transparency isn't new: a lot of research on IT platform complexity has so far focused on transparency by trying to come up with extensive metrics for architecture complexity and its drivers [1, 20, 8, 21]. Our research supports that creating transparency of complexity is a key lever to managing it. But it is only one lever. And beyond 
metrics, decision-makers also need to understand the implication of decisions on those metrics.

2) Create a compelling motivation for avoiding platform complexity. Companies can do so by setting incentives (or penalties) that consider platform complexity. A focus on individual business cases and short-term departmental or business-unit performance encourages local optimization that often increases enterprise-wide platform complexity. In contrast, the case companies encourage enterprise-wide thinking: by adapting their bonus and performance evaluation systems, having executives model behavior supporting enterprise-optimized decisions, as well as setting policies that avoid local benefits while risking a more complex platform for everyone.

3) Redress the power imbalance between those creating and those having to deal with complexity. Even with cross-functional teams, if e.g., country managers always get their way with using e.g., nonstandard systems, little will change in terms of platform complexity. Hence, our case companies also created and empowered roles charged with protecting platforms from complexity (e.g., the IT unit, process owners, etc.). Besides being part of the operational-level cross-functional teams, the respective roles were also included in executivelevel decision-making committees. And policies such as "reversing the burden of proof” help turn an "upward-battle" against complexity into a situation where people have to argue if they want to increase complexity - effectively granting more power to those having to deal with complexity.

Managing platform complexity in the long run is about changing behavior. (This is true even when companies outsource platforms or use cloud-based platforms: for example, without the appropriate incentive systems to drive desired behavior in an outsourcing relationship, handing over a complex platform will not help. And while software-as-a-service platforms can help to limit excessive customization and variety within one system, they don't address proliferation in the number of systems unless behavioral changes happen in parallel.)

Companies that go beyond technical approaches to complexity management and beyond reducing complexity in their platforms 'after the fact' - by pulling on the three identified people- and behaviorrelated levers - will find themselves better positioned to compete in the digital age and avoid turning their digital investment into their legacy headache of the future. We hope that the cases highlighted here inspire executives to adopt policies and practices to complement their IT complexity reduction efforts. And we hope that research on IT complexity will focus even more on these behavioral drivers of IT complexity.

\section{References}

[1] J. Beese, K. Haki, S. Aier and P. Aleatrati Khosroshahi, Drivers and Effects of Information Systems Architecture Complexity: A Mixed-Methods Study, 24th European Conference on Information Systems, Istanbul, Turkey, 2016.

[2] P. Bolton and J. Farrell, "Decentralization, Duplication, and Delay", J of Political Economy, 98 (1990), pp. 803-826.

[3] EIU, The Complexity Challenge - How businesses are bearing up, Economist Intelligence Unit, London, 2011.

[4] R. Elitzur and A. Wensley, "Game theory as a tool for understanding information services outsourcing", Journal of Information Technology 12 (1997), pp. 45-60.

[5] J. Farrell, "Information and the Coase Theorem", Economic Perspectives, 1 (1987).

[6] T. Groves and M. Loeb, "Incentives in a Divisionalized Firm", Management Science 25 (1979), pp. 221-230.

[7] Knowledge@Wharton, Change Management is the Name of the Game for AkzoNobel's CIO Pieter Schoehuijs, 2012.

[8] M. Mocker, What Is Complex About 273 Applications? Untangling Application Architecture Complexity in a Case of European Investment Banking, 42nd Hawaii International Conference on System Sciences, Waikoloa, HI, USA, 2009.

[9] M. Mocker, M. H. Kagan and J. W. Ross, "Continuous Transformation at IBM: Addressing Disruption from New Technologies", MIT Sloan CISR Working Paper (2014).

[10] M. Mocker and J. W. Ross, Architecting Customer Experience at USAA, Thirty Fourth International Conference on Information Systems, Milan, Italy, 2013.

[11] M. Mocker and J. W. Ross, From Savings Mono-Line to Full-Service Bank: Growing ING Direct Spain, Thirty Fifth International Conference on Information Systems, Auckland, New Zealand, 2014.

[12] M. Mocker and J. W. Ross, "Rethinking Business Complexity", MIT Sloan Center for Information Systems Research, Research Briefing, XIII (2013).

[13] M. Mocker, J. W. Ross and P. Ciano, Building a Global Process Standard at the Most International Company on the Earth: DHL Express, Thirty Fifth International Conference on Information Systems, Auckland, New Zealand, 2014.

[14] M. Mocker and E. van Heck, Business-Driven IT Transformation at Royal Philips: Shedding Light on (Un)Rewarded Complexity, Thirty Sixth International Conference on Information Systems, Fort Worth, USA, 2015. [15] M. Mocker, P. Weill and S. L. Woerner, "Revisiting Complexity in the Digital Age", MIT Sloan Management Review, 55 (2014), pp. 73-81-81.

[16] A. Novales, M. Mocker and D. Simonovich, IT-enriched 'digitized' products: building blocks and challenges, 
Proceedings of the 22nd Americas Conference on Information Systems, San Diego, USA (forthcoming), 2016.

[17] M. E. Porter and J. E. Heppelmann, "How Smart, Connected Products are Transforming Companies", Harvard Business Review, 93 (2015), pp. 96-114.

[18] A. Quaadgras, J. W. Ross and C. M. Beath, "Fidelity Investments: Investing in IT for Greater Strategic Impact", MIT Sloan CISR Working Paper (2014).

[19] J. W. Ross, P.; Robertson, David C., Enterprise Architecture As Strategy, Harvard Business School Press, Boston, MA, 2006.

[20] A. W. Schneider, T. Reschenhofer, A. Schuetz and F. Matthes, Empirical Results for Application Landspace Complexity, 48th Hawaii Conference on System Sciences, Kauai, Hawaii, USA, 2015, pp. 4079-4088.

[21] A. Schütz, T. Widjaja and J. Kaiser, Complexity In Enterprise Architectures - Conceptualization And Introduction Of A Measure From A System Theoretic Perspective, 21st European Conference on Information Systems, Utrecht, The Netherlands, 2013.

[22] P. Weill and S. L. Woerner, "Thriving in an Increasingly Digital Ecosystem", MIT Sloan Management Review, 56 (2015), pp. 27-34.

[23] Y. Yoo, O. Henfridsson and K. Lyytinen, "The New Organizing Logic of Digital Innovation: An Agenda for Information Systems Research", Information Systems Research, 21 (2010), pp. 724-735.

\section{Appendix: Quotes referenced in Table 1}

P1: It was a six-month project just to apply a security patch. There are companies that spend less than $€ 7,000$ on that simple SAP adjustment. At Philips, it can be more than triple [...] because of the complexity. So many connections, so many different settings, and highly customized. Now we have to redo almost everything to make sure the system runs. -Edgar van Zoelen, Sr. Director, Head of Delivery, Lighting, Cross sector Digital Enablement, Philips

P2: Each individual business case may make sense from the local perspective, but if you add them up at the global level and start assessing them in the context of our strategy, many of those cases make less sense. [...] So we're building governance around our processes and related IT investments. E.g., Pieter Nota as the Products Business Model Owner sits in SteerCos discussing whether we should allow deviation from the model or not. At this stage you have to create that kind of discipline [...]. It has to come from the top down." -Jeroen Tas, EVP \& CIO, Philips

P3: [In the past] the argument often was, 'I spend $100 \mathrm{~K}$ in making something special in SAP. And I can demonstrate I get $300 \mathrm{~K}$ back in one year. Why not do this?' The real question is, why don't you spend the $100 \mathrm{~K}$ in a domain where you can differentiate in the marketplace? It's not about the individual business case. It's about, where should your money, energy, effort and brain share go? It shouldn't go where you can never make a difference. -Mats Beem, SVP, E2E IT Landscape Simplification, Philips

P4: “The litmus test is: it's a differentiating capability if your customer is willing to pay for it. [...] But if you say it cannot be standard, you'd better bring a lawyer, because then it has to have a legal or a compliance background" —Mats Beem

P5: [IT] won't do anything unless the BPO community, who represent our Markets, Sectors and Functions, acknowledges that this is the right thing to do. We're no longer going to ask some guy in some $B U$ deep down what their needs are. No, we are dealing with [the $\mathrm{BPO}$ ] to prioritize what's going into [the systems]. She is responsible to make sure she gets the input from the markets and sectors. It used to be the other way around: I'm a BU and I need this. - -J. Tas

P6: Real learning happens for $90 \%$ 'on the job, so you need people on the shop floor where the action is to actually raise their hands and ask: "This is not according to the standard, why are you deviating?" To get the right level of discipline [...] The BPE's [... i]n execution they maintain competency levels, drive continuous improvement and check execution against the standard. - Rob Theunissen, End2End Transformation Leader, Philips

U1: Whether you are the company president, CFO, a product manager, or service representative, you have to recognize that your loyalty is to the [...] members. It's really trying to make sure that your choices and decisions provide the most value to your membership. And you have competing priorities and performance objectives that sometimes conflict [...]. You have to make sure that the true measure of performance really is how well you are taking care of your members. -Stuart Parker, EVP \& CFO, USAA

U2: This forces enterprise prioritization as opposed to functional and narrow decision-making. -Wayne Peacock, EVP Member Experience, USAA

U3: Because of 10 years of shared experiences and successes, now business people are the first ones to go, "Don't shortcut, because I want it to be around a long time." -James S. Kuhn, SVP, Project Delivery, USAA

U4: Someone that would just walk in [to a meeting] and listen for a while wouldn't necessarily know [who 
is who]. [...] You have to really take some time and pay attention to what they're doing to identify whether they are a technical person or somebody that has a business responsibility. -Rickey Burks SVP Information Systems Architecture and CTO

U5: In many cases at USAA, the business vision lags the IT vision. If it weren't for [...] the IT organization, we wouldn't have been able to make the progress we've made as quickly, because they've been [...] building for integration since day one to make life simpler and easier for our members.-Wayne Peacock

I1: [IT] is [...] helping [the business] to redefine requirements. And this involvement is from the very beginning of the ideation process. So there's no mismatch between sth. that they want to do and what the architecture can deliver because we already challenge, at very initial stages, the business about different approaches, the implication that their requirements might have in the future implementation and maintainability and sustainability of the platform. -Enrique Avila, CIO ING Direct Spain

I2: Usually, the business comes with many requirements. But maybe only one of them is introducing a lot of complexity, or is going to force us to make a lot of changes. Generally, we challenge them back and say: 'If you are able to alleviate a little bit of this business requirement, we might offer a solution that is more maintainable, more manageable, we'll have it faster, and it will cost you less.' And most of the times they listen very carefully. -Enrique Avila

I3: You may not know the full complexity in product design, but if you design the product, co-operating with the Customer Service team, Ops team and IT people, then you normally will be closer to lowering the complexity. —Daniel Llano, EVP Products \& Strategy

I4: They go to every department [...],they explain how they work and then they see how our values are applied in every department. - Daniel Llano

I5: When we start thinking about any product or any process or any new feature to an existing product, one of the first things, one of the first conversations that we have is with IT. How complex is this process? How do you feel? How do you think it will fit in our IT architecture? Nobody comes into my office and says 'OK, this is a product I want to launch,' without understanding what will be the impact in the whole bank. That can't happen. —Daniel Llano

I6: When we make a decision about a new product for customers, all the departments work very much together. We're all very aware of the difficulties that working in silos can have. [...] We all have to be confident that what we're doing will benefit the bank as a whole and not a single department.-Daniel Llano

I7: In remuneration of employees, it is as important to meet the whole bank's target, as their own targets. Global targets are not only financial; we want a given Net Promoter Score [and] certain scores in satisfactions. So, everybody is aware that success of the bank will not only come by doing my job properly, but by creating value as a bank. -Daniel Llano

I8: We strongly believe that as a counterweight for the functional structure, we need horizontal integration to maintain the culture of mutual challenging. -Werner Zippold, COO ING Direct Spain

I9: There is no way that I go to the management committee and say: 'We're going to do this business and we will earn several million euros and it will be fantastic for the P\&L next year.' If the people in Customer Service or IT don't see it as compliant with our principles, then we will not do it. -Daniel Llano

D1: We have introduced from the end of last year a Global SOP improvement review. It used to be called an "audit." - Ian Sykes, Global Vice President, Network Operations Programs, DHL Express

D2: If [s.o.] thinks that there's a really good idea to streamline processes, improve customer experience, reduce costs or whatever reason, they have every right to submit a change request to the DHL standards organization. - Steve Wells, VP,Strategy and Planning Head, Global Order to Cash Domain, DHL Express

D3: The investment committee makes decisions on application development anything greater than $€ 5,000$. That's how tight the governance is. - German Valencia, EVP DPDHL IT Services

O1: Take the HR process. I kept hearing, "I can't do that in my country because of the laws, or because of the works council, or because that's not our culture." [...] So anytime I heard "There's a law," I'd say, "Show me. Send me the document." And I became the "prove it to me" person. -Kari Barbar, VP, Globally Integrated Enterprise Enablement, IBM

O2: That unique way of pricing, unique way of notifying, whatever it might be in a process-if you think being unique is important to your business or your country, verify that with the client. Here's how you verify it: not only do you ask them does it have value, but are they willing to pay for it? -Linda S. Sanford, SVP, Enterprise Transformation, IBM 